\title{
Ultrasound and light: friend or foe? On the role of intravascular ultrasound in the era of optical coherence tomography
}

\author{
Jennifer Huisman • Marc Hartmann • \\ Clemens von Birgelen
}

Received: 15 December 2010/ Accepted: 6 January 2011/Published online: 20 February 2011

(C) The Author(s) 2011. This article is published with open access at Springerlink.com

\begin{abstract}
More than 20 years after its introduction, intravascular ultrasound (IVUS) has outlived many other intracoronary techniques. IVUS was useful to solve many interventional problems and assisted us in understanding the dynamics of atherosclerosis. It serves as an established imaging endpoint in large progression-regression trial and as an important workhorse in many catheterization laboratories. Nowadays, increasingly complex lesions are treated with drug-eluting stents. The application of IVUS during such interventions can be very useful. Recently, optical coherence tomography (OCT), a light-based imaging technique, has entered the clinical arena. The "omnipresence" of OCT during scientific sessions and live courses with PCI may raise in many the question: Does IVUS have a future in the "era of OCT"? Three review articles, highlighted by this editorial, demonstrate the broad spectrum of current IVUS applications and underline the significant role of IVUS during the last two decades. OCT, the much younger technique, still has to prove its value. Yet OCT is likely to take over
\end{abstract}

J. Huisman · M. Hartmann · C. von Birgelen ( $₫)$ Department of Cardiology, Thoraxcentrum Twente, Medisch Spectrum Twente, Haaksbergerstraat 55, 7513 ER Enschede, The Netherlands e-mail: c.vonbirgelen@mst.nl

C. von Birgelen

MIRA Institute for Biomedical Technology and Technical Medicine, University of Twente, Enschede,

The Netherlands some of the current indications of IVUS as a research tool. In addition, OCT is currently gaining clinical significance for stent optimization during complex interventional procedures. Nevertheless, there is little doubt that IVUS still has a major role in studies on coronary atherosclerosis and for guidance of coronary stenting. Thus, ultrasound and light—are they friend or foe? In fact, both methods are good in their own rights. They are complementary rather than competitive. Moreover, in combination, at least for certain indications, they could be even better.

Keywords Intravascular ultrasound - Optical coherence tomography - Coronary atherosclerosis . Progression-regression - Arterial remodeling . Vulnerable plaque · Drug-eluting stent . Biodegradable vascular scaffolds
Abbreviations
IVUS Intravascular ultrasound
RF Radiofrequency
OCT Optical coherence tomography
TCFA Thin-cap fibroatheromas
PCI Percutaneous coronary intervention
DES Drug eluting stent

\section{Introduction}

More than twenty years after its introduction, intravascular ultrasound (IVUS) is still alive and has 
outlived many other intracoronary techniques that have disappeared from the clinical arena. IVUS has been an "eye-opener" that has helped to solve many interventional problems and assisted us in understanding the dynamics of atherosclerosis, which involves the entire vascular wall during lesion development. IVUS not only serves as an established imaging endpoint in large progression-regression trials, but is also an important workhorse in many catheterization laboratories around the globe. Nowadays, increasingly complex lesions are treated with drug-eluting stents (DES), and the application of IVUS during such percutaneous coronary interventions (PCI) can be very useful. Recently, optical coherence tomography (OCT), a novel light-based invasive imaging technique, has entered the clinical arena. The "omnipresence" of OCT during scientific sessions, during live courses with PCI, and on the front pages of renowned cardiology journals may raise in many the question: Does IVUS - the established technique-have a future in the "era of OCT"?

To answer this question and to fully understand the role of IVUS in the past and at present, it is worthwhile to make a brief step back in time. The introduction of gray-scale IVUS in the late 1980s, stimulated meticulous validation studies [1-5]. Further improvement in IVUS image quality and device miniaturization increased the safety and clinical applicability of this technique. The addition of the third dimension and the possibility to acquire images in an ECG-gated fashion permitted highly reproducible volumetric measurements of plaque and vessel dimensions [6-8]. Subsequently, the development of novel techniques for the analysis of IVUS radiofrequency data provided quantitative information on plaque composition [9-12] that could not be obtained with conventional gray-scale IVUS [13]. In the current issue of the journal, Garcia-Garcia et al. [9] present an interesting overview on the development of gray-scale IVUS and discuss technical similarities and differences between the radiofrequency-based IVUS imaging modalities.

In fact, IVUS allowed for the first time a direct visualization of "the enemy" in vivo by depicting the burden of atherosclerotic changes in the coronary vessel wall. The hypothesis of arterial remodeling, which introduced by Glagov et al. [14] based on their work in vitro, was proven and extended by IVUS research in vivo [15-18]. IVUS demonstrated positive vessel remodeling to be an important feature of both vulnerable and ruptured coronary plaques [16]. Serial examination of the coronary vessel dimensions with IVUS permitted the assessment of true vascular remodeling in vivo $[15,17]$. In these serial studies, a broad spectrum of remodeling behavior was demonstrated; in particular, lumen size of mildly diseased left main coronary arteries depended more on the direction of vessel remodeling than on plaque growth $[15,17]$. Such insight into the dynamic nature of coronary remodeling has had an impact on how interventional cardiologists estimate true vessel size in the context of coronary stenting $[19,20]$.

In addition, IVUS was instrumental in the understanding of the dynamic nature of atherosclerosis progression-regression [18, 21-24]. For the first time, serial IVUS demonstrated in vivo the direct relation between serum cholesterol and the progression of plaque size [22]. Subsequently, large-scale multicenter trials with serial IVUS confirmed the aforementioned observations, and demonstrated the ability of statins to stop disease progression and to induce plaque regression at high doses [18, 21]. Serial IVUS studies provide established surrogate endpoints; this allows the testing of novel drugs with smaller study sample sizes and shorter study durations, which is likely to expedite the process of drug development and testing [21]. Moreover, there is evidence that coronary plaque progression as assessed with serial IVUS is linked with adverse cardiovascular events $[23,24]$. In the current issue of the journal, Gogas et al. [18] shed light on various aspects of coronary remodeling and progression-regression studies with IVUS.

As briefly mentioned above, radiofrequency-based (RF) IVUS techniques were developed to characterize and quantify coronary plaque composition [9-12]. Both technical details and current insights from RFIVUS studies are highlighted in the two review articles by Gracia-Garcia et al. and Gogas et al. [9, 18]. For instance, RF-IVUS derived thin-caped fibroatheromas (TCFA) are thought to be IVUSequivalents of vulnerable plaques based on histopathological criteria [18]. Observations from the PROSPECT study showed a significant association between non-culprit RF-IVUS derived TCFA, assessed at a single point in time, and future coronary event risk [25]. But in fact there is only limited knowledge 
about the fate of RF-IVUS derived TCFA, and therefore, the treatment of non-obstructive lesions with RF-IVUS derived features of plaque vulnerability is still unclear. Recently, a serial study by Kubo et al. [26] suggested quite dynamic changes in RFIVUS derived plaque phenotypes, which questions the value of single-point observations of plaque phenotypes. On the other hand, volumetric assessment of necrotic core volume is highly reproducible and its reduction may reflect plaque stabilization, making this parameter an interesting target for pharmacological intervention trials [27].

OCT-the "new kid on the block"-provides coronary imaging in vivo with a high near field resolution, which results in a superior lumen border detection compared to IVUS. However, OCT has a limited penetration depth, which is an evident shortcoming for the assessment of total vessel size and vascular remodeling, and implies the inferiority of OCT in progression-regression trials compared to IVUS. Yet in the context of vulnerable plaque detection, only OCT is able to depict and measure fibrous caps; this may help to identify plaques prone to rupture $[28,29]$. On the other hand, the relatively user-friendly RF-IVUS analysis method provides quantification of different plaque components (e.g. necrotic core volume) which are displayed in simplified color-coded images. The interpretation of the "pseudo-microscopic" OCT images is more difficult; moreover, the discrimination between lipidic and calcified plaque components can be quite challenging as both can have low image intensities [29]. Considering the advantages and limitations of IVUS and OCT for the assessment of vulnerable plaques, the combined use of RF-IVUS and OCT may improve its detection as recently suggested [28, 29].

Also in target lesions of percutaneous coronary interventions (PCI), careful assessment of plaque composition may be useful, as a large necrotic core recently predicted cardiac marker release after stenting-most likely due to microembolization and/ or induction of a no-reflow phenomenon [30]. For that reason, IVUS assessment before PCI may have the potential to identify lesions at risk of complications and may help to tailor interventional procedures (e.g. use of embolic protection devices and/or direct stenting) [29, 31].

Conventional grayscale IVUS has already proven its particular value in the early 1990s. It demonstrated to the interventional community the shortcomings of that time and was instrumental in developing the concept of optimizing stent expansion by use of balloon catheters with a larger size and higher inflation pressures [32]. In fact, IVUS guidance helped to improve the acute procedural result which greatly prevented (sub)acute stent thrombosis-the main problem in the early days of bare metal stenting $[32,33]$. While various studies suggested that the use of IVUS can result in larger stent dimensions, less restenosis, and reduced need for repeat revascularization procedures, the results of various randomized multicenter studies were not unequivocal with regards to the routine use of IVUS guidance $[34,35]$. Nevertheless, many experts agree that IVUS guidance can be very useful during stenting of bifurcations, left main stems, long lesions, small vessels, and in diabetics [20]. Moreover, the forwardlooking IVUS catheter, which is currently under clinical evaluation, may facilitate the recanalization of chronic total occlusions of coronary arteries. In addition, IVUS can be extremely helpful in the prevention, detection, and management of various complications such as spiral dissections or stentrelated problems.

The introduction of drug-eluting stents (DES) during the first decade of this century virtually abolished the need for repeat PCI to treat instent restenosis. The enthusiasm associated with the early DES results let us believe that IVUS optimization of stenting became much less important [36]. Then, the observation of late and very late stent thromboses in DES represented a "wake-up call" to carefully study the mechanisms involved. Therefore, various IVUS studies were performed and suggested that, besides other factors, DES underexpansion may be particularly important [37-39]. IVUS insights into the failure of DES as well as other stent-related issues are discussed in a review by Brugaletta et al. [40] in the present issue of the journal. IVUS guidance of DES implantation was recently shown to reduce late stent thrombosis and other major adverse cardiac events as well as the need for repeat revascularization [41].

New intracoronary devices, such as bioresorbable vascular scaffolds (BVS), are made of non-metallic materials that are classified by RF-IVUS as being "calcified and necrotic tissue" [42, 43]. Although this classification is obviously incorrect (RF-IVUS is not 
validated for characterization of such material), this technique may help to track the process of bioresorption and integration of biodegradable stent material into the vessel wall [42-46]. Recent data suggest that after bioresorption the "normal" structures of the arterial wall may be partially restored [42]. In the current issue of the journal, Brugaletta et al. [40] present an interesting overview of the IVUS guidance of DES and BVS implantation.

Compared to IVUS, the high-resolution technique OCT provides more detailed information on stent struts and their interaction with the vessel wall. OCT permits, for instance, a more accurate assessment of stent strut apposition to the vessel wall and allows the identification of even very thin neointimal layers during follow-up of DES [47, 48]. In addition, as previously discussed, OCT may complement RFIVUS when identifying vulnerable high-risk lesions before stent implantation [29]. In fact, OCT may also be an interesting tool to study various mechanistical concepts in the clinical setting-concepts that can otherwise only be examined with bench-top research such as micro-computed tomography [49]. Guidance of coronary stenting with OCT has recently been shown to be feasible and safe [46].

However, OCT also has some shortcomings in this particular setting, such as (1) limited assessment of true vessel size, (2) suboptimal clearance of blood by flushing large proximal coronary segments, and (3) lack of computerized plaque tissue detection [47, 48]. Moreover, while we (greatly) know how to interpret IVUS, the enormous amount of detail depicted by OCT requires considerable effort before we will be able to make full use of all the information provided by OCT.

The three review articles, highlighted by this editorial comment, demonstrate the broad spectrum of current IVUS applications and underline the significant role of IVUS during the last two decades. OCT is a much younger technique which still has to prove its value. Yet OCT is likely to take over some of the current indications of IVUS as a research tool. In addition, OCT is currently gaining clinical significance in the field of stent optimization during complex PCI procedures. Nevertheless, there is little doubt that IVUS still has a major role in studies on progression-regression and composition of atherosclerotic plaques as well as for guidance of coronary stenting.
Thus, ultrasound and light-are they friend or foe? In fact, both methods are good in their own rights. They are complementary rather than competitive. Moreover, in combination, at least for certain indications, they could be even better.

\section{Conflict of interest None.}

Open Access This article is distributed under the terms of the Creative Commons Attribution Noncommercial License which permits any noncommercial use, distribution, and reproduction in any medium, provided the original author(s) and source are credited.

\section{References}

1. Linker DT, Yock PG, Grønningsaether A, Johansen E, Angelsen BA (1989) Analysis of backscattered ultrasound from normal and diseased arterial wall. Int J Card Imag 4:177-185

2. Potkin BN, Bartorelli AL, Gessert JM, Neville RF, Almagor Y, Roberts WC, Leon MB (1990) Coronary artery imaging with intravascular high-frequency ultrasound. Circulation 81:1575-1585

3. Mallery JA, Tobis JM, Griffith J, Gessert J, McRae M, Moussabeck O, Bessen M, Moriuchi M, Henry WL (1990) Assessment of normal and atherosclerotic arterial wall thickness with an intravascular ultrasound imaging catheter. Am Heart J 119:1392-1400

4. Ge J, Erbel R, Görge G, Gerber T, Brennecke R, Seidel I, Reichert T, Meyer J (1992) Intravascular ultrasound imaging of arterial wall architecture. Echocardiography 9:475-483

5. Di Mario C, The SH, Madretsma S, van Suylen RJ, Wilson RA, Bom N, Serruys PW, Gussenhoven EJ, Roelandt JR (1992) Detection and characterization of vascular lesions by intravascular ultrasound: an in vitro study correlated with histology. J Am Soc Echocardiogr 5:135-146

6. Bruining N, von Birgelen C, de Feyter PJ, Ligthart J, Li W, Serruys PW, Roelandt JR (1998) ECG-gated versus nongated three-dimensional intracoronary ultrasound analysis: implications for volumetric measurements. Cathet Cardiovasc Diagn 43:254-260

7. von Birgelen C, de Vrey EA, Mintz GS, Nicosia A, Bruining N, Li W, Slager CJ, Roelandt JR, Serruys PW, de Feyter PJ (1997) ECG-gated three-dimensional intravascular ultrasound: feasibility and reproducibility of the automated analysis of coronary lumen and atherosclerotic plaque dimensions in humans. Circulation 96:2944-2952

8. von Birgelen C, Slager CJ, Di Mario C, de Feyter PJ, Serruys PW (1995) Volumetric intracoronary ultrasound: a new maximum confidence approach for the quantitative assessment of progression-regression of atherosclerosis? Atherosclerosis 118(suppl):S103-S13

9. Garcìa-Garcìa HM, Gogas BD, Serruys PW, Bruining N (2011) IVUS- based imaging modalities for tissue characterization: similarities and differences. Int $\mathbf{J}$ Cardiovasc Imag (in press) 
10. Hartmann M, Mattern ES, Huisman J, van Houwelingen GK, de Man FH, Stoel MG, Danse PW, Louwerenburg HW, von Birgelen C (2009) Reproducibility of volumetric intravascular ultrasound radiofrequency-based analysis of coronary plaque composition in vivo. Int $\mathrm{J}$ Cardiovasc Imag 25:13-23

11. Huisman J, Hartmann M, Mattern ES, Mintz GS, Basalus MW, van Houwelingen GK, Verhorst PM, von Birgelen C (2010) Impact of analyzing less image frames per segment for radiofrequency-based volumetric intravascular ultrasound measurements in mild-to-moderate coronary atherosclerosis. Int J Cardiovasc Imag 26: 487-497

12. Huisman J, Egede R, Rdzanek A, Böse D, Erbel R, Kochman J, Jensen LO, van de Palen J, Hartmann M, Mintz GS, von Birgelen C (2010) Between-centre reproducibility of volumetric intravascular ultrasound radiofrequency-based analyses in mild-to-moderate coronary atherosclerosis: an international multicentre study. EuroIntervention 5:925-931

13. Hiro T, Leung CY, De Guzman S, Caiozzo VJ, Farvid AR, Karimi H, Helfant RH, Tobis JM (1997) Are soft echoes really soft? Intravascular ultrasound assessment of mechanical properties in human atherosclerotic tissue. Am Heart J 133:1-7

14. Glagov S, Weisenberg E, Zarins CK, Stankunavicius R, Kolettis GJ (1987) Compensatory enlargement of human atherosclerotic coronary arteries. $\mathrm{N}$ Engl J Med 316: 1371-1375

15. von Birgelen C, Hartmann M, Mintz GS, Böse D, Eggebrecht H, Neumann T, Gössl M, Wieneke H, Schmermund A, Stoel MG, Verhorst PM, Erbel R (2006) Remodeling index compared to actual vascular remodeling in atherosclerotic left main coronary arteries as assessed with long-term ( $>$ or $=12$ months) serial intravascular ultrasound. J Am Coll Cardiol 47:1363-1368

16. von Birgelen C, Klinkhart W, Mintz GS, Papatheodorou A, Herrmann J, Baumgart D, Haude M, Wieneke H, Ge J, Erbel R (2001) Plaque distribution and vascular remodeling of ruptured and nonruptured coronary plaques in the same vessel: an ultrasound study in vivo. J Am Coll Cardiol 37:1864-1870

17. Berry C, Noble S, Ibrahim R, Grégoire J, Levesque S, L'allier PL, Tardif JC (2010) Remodeling is a more important determinant of lumen size than atheroma burden in left main coronary artery disease. Am Heart J 160: 188-194.e1

18. Gogas BD, Farooq V, Serruys PW, Garcia-Garcia HM (2011) Assessment of coronary atherosclerosis by IVUS and IVUS-based imaging modalities: progression and regression studies, tissue composition and beyond. Int $\mathbf{J}$ Cardiovasc Imag (in press)

19. von Birgelen C, Gil R, Ruygrok P, Prati F, Di Mario C, van der Giessen WJ, de Feyter PJ, Serruys PW (1996) Optimized expansion of the Wallstent compared with the Palmaz-Schatz stent: on-line observations with two- and three-dimensional intracoronary ultrasound after angiographic guidance. Am Heart J 131:1067-1075

20. Mintz GS, Painter JA, Pichard AD, Kent KM, Satler LF, Popma JJ, Chuang YC, Bucher TA, Sokolowicz LE, Leon MB (1995) Atherosclerosis in angiographically "normal" coronary artery reference segments: an intravascular ultrasound study with clinical correlations. J Am Coll Cardiol 25:1479-1485

21. Böse D, von Birgelen C, Erbel R (2007) Intravascular ultrasound for the evaluation of therapies targeting coronary atherosclerosis. J Am Coll Cardiol 49:925-932

22. von Birgelen C, Hartmann M, Mintz GS, Baumgart D, Schmermund A, Erbel R (2003) Relation between progression and regression of atherosclerotic left main coronary artery disease and serum cholesterol levels as assessed with serial long-term ( $>$ or $=12$ months) follow-up intravascular ultrasound. Circulation 108:2757-2762

23. von Birgelen C, Hartmann M, Mintz GS, van Houwelingen KG, Deppermann N, Schmermund A, Böse D, Eggebrecht H, Neumann T, Gössl M, Wieneke H, Erbel R (2004) Relationship between cardiovascular risk as predicted by established risk scores versus plaque progression as measured by serial intravascular ultrasound in left main coronary arteries. Circulation 110:1579-1585

24. Nicholls SJ, Hsu A, Wolski K, Hu B, Bayturan O, Lavoie A, Uno K, Tuzcu EM, Nissen SE (2010) Intravascular ultrasound-derived measures of coronary atherosclerotic plaque burden and clinical outcome. J Am Coll Cardiol 55:2399-2407

25. Stone GW (2009) Prospect trial: a natural history study of atherosclerosis using multimodality intracoronary imaging to prospectively identify vulnerable plaque. TCT: Late-Breaking Clinical Trial 24-09-2009

26. Kubo T, Maehara A, Mintz GS, Doi H, Tsujita K, Choi SY, Katoh O, Nasu K, Koenig A, Pieper M, Rogers JH, Wijns W, Böse D, Margolis MP, Moses JW, Stone GW, Leon MB (2010) The dynamic nature of coronary artery lesion morphology assessed by serial virtual histology intravascular ultrasound tissue characterization. J Am Coll Cardiol 55:1590-1597

27. Serruys PW, García-García HM, Buszman P, Erne P, Verheye S, Aschermann M, Duckers H, Bleie O, Dudek D, Bøtker HE, von Birgelen C, D'Amico D, Hutchinson T, Zambanini A, Mastik F, van Es GA, van der Steen AF, Vince DG, Ganz P, Hamm CW, Wijns W, Zalewski A (2008) Integrated biomarker and imaging study-2 investigators. Effects of the direct lipoprotein-associated phospholipase $\mathrm{A}(2)$ inhibitor darapladib on human coronary atherosclerotic plaque. Circulation 118:1172-1182

28. Goderie TP, van Soest G, Garcia-Garcia HM, Gonzalo N, Koljenović S, van Leenders GJ, Mastik F, Regar E, Oosterhuis JW, Serruys PW, van der Steen AF (2010) Combined optical coherence tomography and intravascular ultrasound radio frequency data analysis for plaque characterization. Classification accuracy of human coronary plaques in vitro. Int J Cardiovasc Imag 26:843-850

29. Sawada T, Shite J, Garcia-Garcia HM, Shinke T, Watanabe $\mathrm{S}$, Otake H, Matsumoto D, Tanino Y, Ogasawara D, Kawamori H, Kato H, Miyoshi N, Yokoyama M, Serruys PW, Hirata K (2008) Feasibility of combined use of intravascular ultrasound radiofrequency data analysis and optical coherence tomography for detecting thin-cap fibroatheroma. Eur Heart J 29:1136-1146

30. Böse D, von Birgelen C, Zhou XY, Schmermund A, Philipp S, Sack S, Konorza T, Möhlenkamp S, Leineweber K, Kleinbongard P, Wijns W, Heusch G, Erbel R (2008) Impact 
of atherosclerotic plaque composition on coronary microembolization during percutaneous coronary interventions. Basic Res Cardiol 103:587-597

31. Hong YJ, Jeong MH, Choi YH, Ko JS, Lee MG, Kang WY, Lee SE, Kim SH, Park KH, Sim DS, Yoon NS, Youn HJ, Kim KH, Park HW, Kim JH, Ahn Y, Cho JG, Park JC, Kang JC (2009) Impact of plaque components on no-reflow phenomenon after stent deployment in patients with acute coronary syndrome: a virtual histology-intravascular ultrasound analysis. Eur Heart J. doi: 10.1093/eurheartj/ ehp034

32. Colombo A, Hall P, Nakamura S, Almagor Y, Maiello L, Martini G, Gaglione A, Goldberg SL, Tobis JM (1995) Intracoronary stenting without anticoagulation accomplished with intravascular ultrasound guidance. Circulation 91:1676-1688

33. de Jaegere P, Mudra H, Figulla H, Almagor Y, Doucet S, Penn I, Colombo A, Hamm C, Bartorelli A, Rothman M, Nobuyoshi M, Yamaguchi T, Voudris V, di Mario C, Makovski S, Hausmann D, Rowe S, Rabinovich S, Sunamura M, van Es GA (1998) Intravascular ultrasoundguided optimized stent deployment. Immediate and 6 months clinical and angiographic results from the Multicenter Ultrasound Stenting in Coronaries Study (MUSIC Study). Eur Heart J 19:1214-1223

34. Fitzgerald PJ, Oshima A, Hayase M, Metz JA, Bailey SR, Baim DS, Cleman MW, Deutsch E, Diver DJ, Leon MB, Moses JW, Oesterle SN, Overlie PA, Pepine CJ, Safian RD, Shani J, Simonton CA, Smalling RW, Teirstein PS, Zidar JP, Yeung AC, Kuntz RE, Yock PG (2000) Final results of the can routine ultrasound influence stent expansion (CRUISE) study. Circulation 102:523-530

35. Russo RJ, Silva PD, Teirstein PS, Attubato MJ, Davidson CJ, de Franco AC, Fitzgerald PJ, Goldberg SL, Hermiller JB, Leon MB, Ling FS, Lucisano JE, Schatz RA, Wong SC, Weissman NJ, Zientek DM (2009) A randomized controlled trial of angiography versus intravascular ultrasound-directed bare-metal coronary stent placement (the AVID Trial). Circ Cardiovasc Interv 2:113-123

36. Maluenda G, Pichard AD, Waksman R (2010) Is there still a role for intravascular ultrasound in the current practice era? EuroIntervention 6(suppl G):G139-G144

37. Sonoda S, Morino Y, Ako J, Terashima M, Hassan AH, Bonneau HN, Leon MB, Moses JW, Yock PG, Honda Y, Kuntz RE, Fitzgerald PJ, SIRIUS Investigators (2004) Impact of final stent dimensions on long-term results following sirolimus-eluting stent implantation: serial intravascular ultrasound analysis from the sirius trial. J Am Coll Cardiol 43:1959-1963

38. Okabe T, Mintz GS, Buch AN, Roy P, Hong YJ, Smith KA, Torguson R, Gevorkian N, Xue Z, Satler LF, Kent KM, Pichard AD, Weissman NJ, Waksman R (2007) Intravascular ultrasound parameters associated with stent thrombosis after drug-eluting stent deployment. Am J Cardiol 100:615-620

39. Garcia-Garcia HM, Gonzalo N, Kukreja N, Alfonso F (2008) Greyscale intravascular ultrasound and IVUSradiofrequency tissue characterisation to improve understanding of the mechanisms of coronary stent thrombosis in drug-eluting stents. EuroIntervention 4(suppl C): C33-C38
40. Brugaletta S, Ribamar Costa Jr J, Garcia-Garcia HM (2011) Assessment of drug-eluting stents and bioresorbable stents by grayscale IVUS and IVUS-based imaging modalities. Int J Cardiovasc Imag (in press)

41. Roy P, Steinberg DH, Sushinsky SJ, Okabe T, Pinto Slottow TL, Kaneshige K, Xue Z, Satler LF, Kent KM, Suddath WO, Pichard AD, Weissman NJ, Lindsay J, Waksman R (2008) The potential clinical utility of intravascular ultrasound guidance in patients undergoing percutaneous coronary intervention with drug-eluting stents. Eur Heart J 29:1851-1857

42. Serruys PW, Ormiston JA, Onuma Y, Regar E, Gonzalo N, Garcia-Garcia HM, Nieman K, Bruining N, Dorange C, Miquel-Hébert K, Veldhof S, Webster M, Thuesen L, Dudek D (2009) A bioabsorbable everolimus-eluting coronary stent system (ABSORB): 2-year outcomes and results from multiple imaging methods. Lancet 373:897-910

43. García-García HM, Gonzalo N, Pawar R, Kukreja N, Dudek D, Thuesen L, Ormiston JA, Regar E, Serruys PW (2009) Assessment of the absorption process following bioabsorbable everolimus-eluting stent implantation: temporal changes in strain values and tissue composition using intravascular ultrasound radiofrequency data analysis. A substudy of the ABSORB clinical trial. EuroIntervention 4:443-448

44. Erbel R, Di Mario C, Bartunek J, Bonnier J, de Bruyne B, Eberli FR, Erne P, Haude M, Heublein B, Horrigan M, Ilsley C, Böse D, Koolen J, Lüscher TF, Weissman N, Waksman R (2007) Temporary scaffolding of coronary arteries with bioabsorbable magnesium stents: a prospective, non-randomised multicentre trial. Lancet 369:1869-1875

45. Onuma Y, Serruys PW, Perkins LE, Okamura T, Gonzalo N, Garcia-Garcia HM, Regar E, Kamberi M, Powers JC, Rapoza R, van Beusekom H, van der Giessen W, Virmani $R$ (2010) Intracoronary optical coherence tomography and histology at 1 month and 2, 3, and 4 years after implantation of everolimus-eluting bioresorbable vascular scaffolds in a porcine coronary artery model. An attempt to decipher the human optical coherence tomography images in the absorb trial. Circulation 122:2288-2300

46. Imola F, Mallus MT, Ramazzotti V, Manzoli A, Pappalardo A, di Giorgio A, Albertucci M, Prati F (2010) Safety and feasibility of frequency domain optical coherence tomography to guide decision making in percutaneous coronary intervention. EuroIntervention 6:575-581

47. Gonzalo N, Escaned J, Alfonso F, Jiménez-Quevedo P, Zakhem B, Bañuelos C, Hernández-Antolín R, Macaya C (2010) Is refined OCT guidance of stent implantation needed? EuroIntervention 6(suppl G):G145-G153

48. Prati F, Regar E, Mintz GS, Arbustini E, Di Mario C, Jang IK, Akasaka T, Costa M, Guagliumi G, Grube E, Ozaki Y, Pinto F, Serruys PW (2010) Expert review document on methodology, terminology, and clinical applications of optical coherence tomography: physical principles, methodology of image acquisition, and clinical application for assessment of coronary arteries and atherosclerosis. Eur Heart J 31:401-415

49. Basalus MW, van Houwelingen KG, Ankone MJ, Feijen J, von Birgelen C (2010) Micro-computed tomographic assessment following extremely oversized partial postdilatation of drug-eluting stents. EuroIntervention 6:141-148 